\title{
TERMINOLOGICAL DISCIPLINE AND TERMINOLOGICAL CREATIVITY OF THE TECHNO-EDUCATOR
}

\author{
Ján STOFFA, Univerzita Palackého v Olomouci, Česká republika
} Veronika STOFFOV $\boldsymbol{A}^{*}$, Univerzita Palackého v Olomouci, Česká republika

Přijato: 9. 8. 2018 / Akceptováno: 7. 1. 2019

Typ článku: Teoretická studie

DOI: $10.5507 /$ jtie.2019.001

Abstract: The contribution responds to the unsatisfactory state of the use of terms in the teaching practice of techno-educators (technology teachers). It is manifested by insufficient preparation of techno-educators in the field of terminology, as well as shortcomings in their terminological and language competence. The negative consequence of this state is the underestimation of terminology and a frequent failure to respect the principles of scientific terminology, normalization of technical terminology and the terminological usage of the professional community. Significant shortcomings also appear in relation to the language accuracy of the terms used.

The main objective of the study is to highlight the importance of adherence of the terminological discipline in the acquisition of terminology in educational processes, illustrate the most frequent terminological shortcomings and errors recorded by the authors of this study in their multi-year educational practice and to assess the publication and presentation outputs of techno-educators.

A further goal is to clarify the position of techno-educators in relation to terminology and to define the space in which techno-educators can apply creativity. The third objective is to formulate recommendations to improve terminological discipline and broaden the use of creativity for the acquisition of terminology in educational processes.

Key words: terminological discipline, terminological creativity, most common terminology-errors and deficiencies.

\section{TERMINOLOGICKÁ DISCIPLÍNA A TERMINOLOGICKÁ KREATIVITA TECHNOEDUKÁTORA}

Abstrakt: Príspevok reaguje na neuspokojivý stav použivania termínov vo vyučovacej praxi technoedukátorov (učitelov technicky orientovaných predmetov). Prejavuje sa tak nedostatočná príprava technoedukátorov v oblasti terminológie a nedostatky $v$ ich terminologickej a jazykovej kompetencii. Negatívnym dôsledkom tohto stavu je podceňovanie terminológie a časté nerešpektovanie princípov termínovedy, normalizácie technickej terminológie 
a zvyklostí odbornej komunity. Značné nedostatky sa objavujú aj z hl'adiska jazykovej správnosti použivaných termínov

Hlavným ciel'om štúdie je objasnit' dôležitost' dodržiavania terminologickej discipliny pri osvojovaní terminológie vo vzdelávacích procesoch a poukázanie na najčastejšsie terminologické nedostatky a chyby zaznamenané autormi tejto štúdie počas mnohoročnej vzdelávacej praxe a pri posudzovaní publikačných a prezentačných výstupov technoedukátorov.

Ďalš́m cielom je objasnit' pozíciu technoedukátorov vo vztahu $k$ terminológii a definovat' priestor, v ktorom môžu technoedukátori uplatnit' tvorivost'. Tretím cielom je formulovat' odporúčania na zlepšenie terminologickej disciplíny a zvýšenie tvorivosti pri osvojovani terminológie vo vzdelávacích procesoch.

Klíčová slova: terminologická disciplína, terminologická kreativita, najčastejšie terminologické chyby a nedostatky.

\footnotetext{
*Autor pro korespondenci: NikaStoffova@seznam.cz
}

\section{Introduction}

Aside from a small number of exceptions, techno-educators (technology teachers) in their teaching practice cannot avoid the use of many terms which represent concepts in communication. Building a conceptual system and acquiring a conceptual apparatus is so closely related to the terms that, in a sense, it is also possible to talk about the construction of a term system, which is a communication counterpart of the conceptual system, because it is irrational and practically very cumbersome to represent by their definitions in communication. While the content of a concept can express many differently formulated definitions, a well-chosen and settled term unambiguously represents a concept. Nevertheless, it must always be borne in mind that the acquisition of a concept consists in acquiring both the content of the concept (expressed by its definition) and the term assigned to it (representing the unequivocal substitution of the concept in communication) must always be realized simultaneously. While mastering the concepts of technology is a matter of prime importance in techno-education, the acquisition of terms is underestimated, it being generally assumed that learners (pupils, students and adult learners) will acquire the terms without special effort.

The aim of this study is to call attention to the unsatisfactory state of the use of terms in techno-education teaching practice, which we have repeatedly pointed out, e.g. in (1). This is manifested by the insufficient preparation of educators in the field of terminology and the deficiencies in their terminological insufficient preparation of educators in the field of terminology and the deficiencies in their terminological literacy and language culture. The negative consequence of this state is the underestimation of terminology and the frequent failure to respect the principles of terminology science, the standardization of technical terminology and the terminological usage of the professional community. Significant shortcomings are also manifested in relation to suitable language accuracy with respect to the terms used.

The main objective of the study is to contribute to the clarification of the concepts of terminological discipline and terminological creativity, which we consider to be organic 
components of the terminological competence of a techno-educator, and to point out their importance in education. Another goal is to clarify the position of techno-educators in relation to terminology and to indicate a space in which techno-educators can apply terminological creativity.

Another objective of this study is to show that the acquisition of terms in technoeducation presupposes significant terminological erudition of the techno-educator, of which the main components are terminological literacy and terminological culture, which we have more closely characterized in studies (2), (3) and (4). Both can be considered as components of information and communication competence (5). The absence of this erudition can cause learners to acquire the relevant terms superficially or even incorrectly. This study also strives to point out the most serious and most frequent terminological errors and deficiencies that techno-educators often commit in their teaching practice.

\section{Content of the terminological literacy of the techno-educator concept}

Terminological literacy of the techno-educator is a complex and yet only partially clarified concept. Its minimum level can be called the terminological minimum of a technoeducator. It includes the knowledge presented in the study (6). We consider it necessary to emphasize these of its components:

- $\quad$ acquisition of the theoretical basis of terminology as an interdisciplinary science discipline, its principles and basic concepts;

- acquisition of the properties of an ideal term, which should have as many real terms as possible;

- knowledge of the causes and nature of deviations of the properties of real terms in comparison with the properties of the ideal term;

- knowledge of the conceptual system of the user's branch or his/her field of activity;

- $\quad$ knowledge of conceptual systems of related disciplines;

- acquisition of terminology of user's field of activity;

- knowledge of special terminological standards, universal standards and community usage in the field of the user's activity;

- knowledge of different abbreviation equivalents of verbal terms;

- knowledge of non-verbal equivalents of terms;

- knowledge of global trends in the field of terminology;

- knowledge of substandard term counterparts of established standard terms so that they can be reacted to when used by learners in the educational process;

- ability to evaluate the reliability of terminological information sources and use them efficiently;

- ability to verify the correct spelling and pronunciation of the terms used;

- ability to apply a critical approach when retrieving terminological information from a variety of sources.

In some branches (e.g. in medicine, chemistry, law) considerable attention is paid to the acquisition of terminological literacy. However, with a few exceptions, special terminological preparation is lacking in educational and technical branches. This results 
in a large number of terminological errors and deficiencies in the written and spoken communication of terminology users.

\section{The content of the terminological culture of the techno-educator concept}

A more detailed view of scientific and professional communication shows that the transfer of information can be reliably realized at a substandard level as well. In education, however, such a level is unacceptable, and the techno-educator is obliged to utilize educational communication at a high cultural level. One of the prerequisites for this is the high terminological culture of the educator. This concept is not yet fully explained. From among its basic components we would like to highlight:

- a consistent distinction between the terms as communication equivalents of concepts and other designations such as non-terms, half-terms, names of particular or specific material and fiction objects, colloquial expressions and substandard designations;

- the ability to verify whether a foreign-language term is in the vocabulary of the language in which the education is being practiced and, if it belongs, the ability to identify the correct written and spoken form of such a term;

- avoiding shortened term forms without initial clarification of their full forms or without an explanation of their meanings.

Terminological literacy and terminological culture are the fundamental components of the terminological competence of the user. As its minimum we consider the knowledge presented in the study (6) and in timeless monographs (7) and (8).

\section{Content of the terminological discipline of the techno-educator concept}

The techno-educator is usually not the creator, but only the user of terminology. As a user, he /she must maintain terminological discipline. This includes:

- consistent use of actual standardized terms if they were subject to standardization;

- consistent compliance with the usage, practice and customs of the relevant professional community, if the term is not standardized;

- $\quad$ preference of clear national terms in general education and introduction of their international equivalents in specialized professional training;

- consistent use of one term or its abbreviation in communication;

- consistent use only one form of a term from permitted alternative forms of the term;

- if there are several synonymous variants of the term, the techno-educator is required to present them all when first using the preferred synonymous term and consequently justify the preference;

- on the first use of the term, the content of the corresponding concept should also be presented, using a suitable didactically transformed definition of the concept;

- responding to terminological errors and deficiencies committed by learners and providing appropriate explanations. 


\section{Content of the concept terminological creativity of the techno-educator}

Terminological discipline has an imperative character in the educational practice, from both a professional and a language aspect. Considering the necessity of adherence to terminology discipline, it may seem that the techno-educator no longer has any space for terminological creativity. In fact, although limited, such a space does exist. This space is largest in the area of formulating the definitions of acquired concepts which should be on principle acquired simultaneously with the term as a communication equivalent. The techno-educator may exhibit creativity when choosing from a set of definitions available in professional literature. Didactic transformations of definitions created by experts and addressed to specialists have much more space for creativity. Such definitions are not as a rule suitable in education processes and must be didactically transformed with respect to the age and prior preparation of learners.

The techno-educator can also apply creativity in the creation of one's own, generally simplified definitions, which respect the relationships between subjects and only operate with the concepts already adopted by the learners. Creativity can also be used when designing various verbal puzzles. Such puzzles can serve as instruments for checking the knowledge of terms in classic puzzles as well as the ability of learners to formulate definitions of given concepts in reverse puzzles. In the straightforward puzzle learners should assign the correct term to a concept presented by its definition as given by the teacher, while in the reverse puzzle terms are given by the teacher and the learners should create their own definitions of the corresponding concepts. The use of one of these types of word puzzles has been discussed in more detail in the study (9).

An important space for creativity is also provided by assessments of the inappropriateness of substandard counterparts of terms used by learners. The technoeducator can help them to find the correct standard terms and explain the nature of the mistakes.

A creative approach can also be applied by the techno-educator in other ways, e.g.:

- when choosing the best term from a set of allowed synonym equivalents of a term;

- in explaining the possible loss or distortion of information in the case of falsely orienting homonymous terms;

- in explaining the content of new concepts (neologisms), often from foreign languages, with vague spelling and pronunciation. Since neologisms are absent not only in textbooks and teaching aids, but also oft in commonly available information sources, the techno-educator can create his own descriptive definitions of their content;

- by pointing out the existence of a large and constantly increasing number of non-verbal equivalents of terms (marks, symbols, abbreviations, acronyms, pictograms, ideograms, icons, etc.) in the field of technical and technological branches, applied informatics and ICT, and by clarifying their origin, meanings and equivalence. The monograph (10) deals in more detail with the significance and forms of technical non-verbal communication;

- using the etymology of terms to facilitate the memorization of non-speculative foreign language terms or terms of foreign language origin. For this purpose special etymological dictionaries of the type (11) can be used. 


\section{The most frequent and most serious terminological errors and deficiencies}

In assessing hundreds of spoken and written communications, we have encountered a wide range of terminological errors and deficiencies. Many of them have been pointed out in several studies, e.g. (12), in reviews, and review reports. For the limited scope of this study, we will only mention those types which we consider to be the most serious, most relevant and most frequent:

1. Many term users do not distinguish between terms (naming abstract objects) and other designations (designations of particular specific objects). The most widespread case is the non-differentiation of the concept of the internet (international network in a general sense) and the Internet (commercial name of a particular licensed international network).

2. Many Slovak users use improper terms instead of correct ones, e.g. manager, management, menežovat' (correctly manažér, manažment, manažovat').

3. Many Slovak users use terms that were standard in the past but have been excluded for various reasons: kysličník kremičitý, termoset, umelá hmota (correctly oxid kremičitý, reaktoplast, plast).

4. Many Slovak users use colloquial expressions that do not belong in standard professional or educational communication, e.g. cedečko, comp, dial'nopis (correctly kompaktný disk or kompaktná platňa, osobný počitač, d'alekopis).

5. Many Slovak users use obsolete terms that were phased out many years ago, for example, dielektrická konštanta, elektromotorická sila, koercitívna sila (correctly elektrická permitivita, elektromotorické napätie, koercitivita).

6. Explanations of initials (equivalent abbreviations of multi-word terms) which are not independent names, are reported such that every word of the full term is written with a capital letter at the beginning, e.g. „CD-ROM (Compact Disk Read Only Memory)" (13, p. 34). The user may think that the full term should also be written in the context. Since no part of this multi-word term is an independent name, there is no reason to write the term in this form in a context. The correct explanation in the case should be: CD-ROM (compact disc read-only memory). If it is desired to indicate how this abbreviation is derived, this can be achieved by highlighting the first letters in bold, i.e. CD-ROM (compact disk read-only memory).

7. Many Slovak users use an incorrect pronunciation of the abbreviation of the Latin term philosophiae doctor - PhD. They spell it as if it were English, i. e. pee ejtch dee. The correct Slovak pronunciation is pé há dé.

8. Many Slovak users use Czech terms in Slovak context, for example, čidlo (correctly snimač, senzor, or detektor).

9. Many Slovak users do not respect changes in over the adoption of foreign language terms and use the original, now already substandard forms of terms, e.g. design, hardware, software (correctly dizajn, hardvér, softvér). 


\section{Conclusions and recommendations}

As we have repeatedly emphasized, terminology is the lifelong task of each educator (14). We can argue that in the case of techno-educators, this task is harder and more complicated, especially in light of the exponential increase in scientific, technical and technological knowledge and the emergence of a whole range of new technical and technological or border-related disciplines. This is also reflected in the terminology developmental trends we have attempted to characterize in studies (15) and (16).

Conceptual systems and terminology are an important part of techno-education, which cannot be done well without the sufficient terminology competence of techno-educators. Its components are terminological literacy, terminological culture, terminological discipline and terminological creativity. Therefore, terminological training should become an organic part of the training of techno-educators. Proper use of terms should be paid attention to not only in education itself but also in the development of educational documents, textbooks, teaching aids and specialist literature. Similar considerations apply to all forms of presentation of special and scientific knowledge to the public.

Based on our findings, it can be argued that a techno-lecturer is usually only a qualified user of terms created by other persons or corporations, rather than their creator. It follows that a techno-lecturer should acquire and respect the concept system and terminology of his / her professional discipline and also know its relations with similar systems of a considerable number of basic and relative, respectively border, fields. A part of this knowledge is also acquiring the standard forms of important terms, both written and spoken. For educational reasons, however, the techno-educator must also know colloquial and substandard counterparts of standard terms to respond to them in cases where they are improperly used by learners. For this purpose, the techno-educator has to develop lifelong training in the field of terminology and reflect development trends in terminology as well as changes in the conceptual system and terminology of his discipline.

Terminological competence and erudition cannot be acquired once and for ever. There is ongoing development in the area of terminology. Existing interdisciplinary relationships are deepening and new interdisciplinary relationships are appearing. This is also shown in the terminology of individual scientific disciplines. The erudition that a techno-lector receives at the beginning of his professional career is only sufficient for a limited time. For this reason, it must not only be sustained but constantly improved and enriched by various forms of lifelong learning.

\section{Bibliography}

Stoffa, J. (2002). Súčasný stav slovenskej technickej terminológie a terminológie didaktiky technických predmetov [Contemporary state of Slovak technical terminology and terminology of didactic of technical subjects]. In: ŠVEC, Š. et al.: Jazyk vied o výchove. Bratislava : Gerlach print and Filozofická fakulta Univerzity Komenského, pp. 92-100. Štofa, J. (1992). Terminologická kultúra učitel'a technickej výchovy [Terminological culture of the technology teacher]. In: Současné celosvětové otázky alternativního školství... Olomouc : Universitas Palackianae Olomucensis, Facultas paedagogica, p. $28-29$.

Stoffa, J. (2009). Terminologická gramotnost' a terminologická kultúra [Terminological literacy and terminological culture]. In: Terminologické fórum II: na tému 
socioterminológia, textová a prekladová terminológia. Ed. Ingrid Cíbiková. 1st ed. Trenčín : Trenčianska univerzita A. Dubčeka. [Article on CD-ROM]

Stoffa, J., \& Stoffová, V. (2015). Teacher's terminological competence. In: Edukacja wczoraj - dziś - jutro Edukacja w dialogu pokoleńi budowaniu lepszej przyszłości. Red. E. Sałata, M. Mazur and J. Bojanowicz. 1st. ed. Radom : Radomskie Towarzystwo Naukowe, p. 457-464.

Stoffová, V. \& Stoffa, J. (2004). Informačné a komunikačné kompetencie edukátorov $\mathrm{v}$ informačnej spoločnosti [Information and communication competences of educators in information society]. In: Trendy technického vzdělávání 2004: Technická a informační výchova : Sborník mezinárodní konference (dodatky). 1st ed. Olomouc : Votobia Praha, p. 102-113.

Stoffa, J. \& Stoffová, V. (2008). Terminologické minimum edukátorov [Terminological minimum of educators]. In: Informatika v škole a v praxi. Ed. Igor Černák, Eduard Mašek and Janka Majherová. Ružomberok : Pedagogická fakulta Katolíckej univerzity v Ružomberku, Katedra informatiky, p. 98-106.

Stoffa, J. (2000). Terminológia v technickej výchove [Terminology in techno-education]. 2nd rewised and supplemented ed. Olomouc : Univerzita Palackého v Olomouci.

Stoffa, J. \& Stoffová, V. (2017) Terminológia v informatike a IKT [Terminology in informatics and ICT]. 1st ed. Trnava - Bratislava : Trnavská univerzita - VEDA.

Stoffa, J. (1997). Didaktická doplňovačka vo vzdelávacom procese [Didactic word puzzle in instruction process]. In: Zbornik MEDACTA '97 : Zväzok 5. Compilers. P. Bohony and P. Konečný. 1st ed. Nitra : Slovdidac, p. 1491-1495.

Tomková, V. (2013). Technická neverbálna komunikácia [Technical non-verbal communication]. 1st. ed. Nitra : Pedagogická fakulta UKF.

Králik, L. (2015). Stručný etymologický slovník slovenčiny [A brief etymological dictionary of Slovak]. 1st ed. Bratislava : Veda - Jazykovedný ústav L'udovíta Śtúra SAV. Stoffa, J. \& Stoffová, V. (2014). Časté chyby pri používaní termínov anglického pôvodu $\mathrm{v}$ slovenskom pojmosloví IKT [Frequent errors in using of terms of English origin in Slovak terminology of ICT]. In: Sbornik z mezinárodní konference XXVII. DIDMATTECH 2014. Ed.: V. Stoffová, M. Chráska, M. Klement and M. Havelka. 1st ed. Olomouc : Univerzita Palackého, Pedagogická fakulta, p. 73-76.

Slováček, J. (2000). Slovník anglických zkratek : English abbreviations dictionary. Ostrava: Montanex.

Stoffa, J. \& Stoffová, V. (2011). Terminológia - celoživotný údel každého edukátora [Terminology - lifelong destiny of each educator]. In: Eruditio - Educatio, 6 (1), p. 3-14. Stoffa, J. (2008). Súčasné tendencie vo vývoji vedeckej terminológie a ich dôsledky $\mathrm{v}$ edukácii [Current trends in the development of scientific terminology and their consequences in education]. In: XXVI. International colloquium on the Management of Educational Process : Proceeding of abstracts and electronic version of reviewed contributions on CD-ROM. Ed. E. Hájková and R.Vémolová. Brno : University of Defence, Faculty of Economics and Management. Abstract on p. 78, full article on CD-ROM.

Stoffa, J. \& Stoffová, V. (2016). Contemporary trends and problems of scientific terminology. In: Prezent Day Trends of Innovations 6. Ed. L. Várkoly, R. Szczebiot and M. Zábovský. 1st ed. Lomźa - Printing House of Lomza State University of Applied Sciences, p. 176-183. 